\title{
INDIVIDUAL LIVES AND FAMILY STRATEGIES IN THE FRENCH PROLETARIAT*
}

\author{
Louise A. Tilly**
}

During his imprisonment in Fascist Italy, Antonio Gramsci was deprived of everyday contacts with people and grasped at the scraps of reading material that came his way. It was under these conditions that he wrote his thoughtful and stimulating prison notebooks and letters. In a letter to his sister-in-law Tatiana in 1928, he remarked, "If you're not able to understand real individuals, you can't understand what is universal and general" (Lawner, 1973:136).

This aphorism strikes at one of the central problems of the practice of social history. In their commitment to seeking out the history of the inarticulate popular classes, social historians have necessarily turned to sources which tell about people rather than sources created by the people themselves. The typical records used by social historians-censuses, marriage, birth and death registers, tax records, police and court records-and the typical methods of analysis of these records produce collective, not individual biogra-

*An earlier draft of this paper, titled "Women and Family Strategies in French Proletarian Families," was written while the author was a fellow at the Davis Center for Historical Studies, Princeton University. That draft was read at Yale University, Livingston College (Rutgers) and the University of California, Santa Cruz. The author wishes to thank colleagues and the audience at those presentations for questions and comments.

**Louise A. Tilly, Ph.D., is Associate Professor of History at the University of Michigan, Ann Arbor. She and Kathryn Tilly are preparing an English translation of Mémé Santerre, to be published by Schocken Books. She is also completing research for a book, Family and Class in Three French Cities. phies. The historical product is description and analysis of behavior patterns by categories of individuals.

Alan Macfarlane (1977:204-205) contrasts the data which are the stuff of social history-"data . . . almost all at the level of behavior, describing events in the past, rather than at the normative or cognitive level" - with the data of contemporary investigators. The latter "often have a plethora of data at the normative levelpeople's comments on how one ought to behave in these ways-but rather little information about how they actually do behave. Thus investigators are forced to infer the statistical level from the normative data, whereas with [historical] material ... we have to deduce the patterns of motivation from the patterns of action."

For the historian one path to normative evidence can lead through autobiography - diaries, memoirs, correspondence. Macfarlane's own masterful analysis (1970) of the diary of Ralph Josselin is one of the most successful examples of the genre. His methodological handbook for the study of historical communities (1977) not surprisingly both catalogs statistical sources for collective biography and argues for the importance of personal testimony. Most social historians are not lucky enough to find in ready conjuncture a well-documented village like Earls Colne and a centrally-placed, long-lived diarist like its seventeenth century parson, Ralph Josselin. For these social historians, however, contemporary autobiographical materials from other places can suggest questions, comparisons, answers to verify and apply in their own community studies. Such is 
the method used in this paper.

Although autobiography can provide precious clues about personal motives and feelings, it is not very helpful in generalizing about behavior. An individual may discuss why he or she acted in some particular way rather than another, from his or her own point of view. From the center of a set of economic and material relationships and social connnections, however, it is difficult for an individual to see patterns of behavior. Such "typical" patterns can be discerned and described by looking not at one individual but at many individuals in similar circumstances, and the connections among these individuals. Clearly social historians need to approach their subjects with as rich and varied a set of sources as possible. Individual biography and collective biography can complement each other in describing behavior and suggesting motives and causes.

One way to conceptualize and examine the links between individual lives and collective behavior is through the concept of family strategies. The concept of family strategies is analytically useful to the social historian seeking to understand the behavior of ordinary people in the pastpeople who, even if they have left autobiographical statements, are seldom aware of what in their lives is unique and what they share with others acting in response to similar constraints and opportunities. Analysis of strategy tries to uncover the principles which lead to observable regularities or patterns of behavior among households. It asks who participates in making decisions, what concerns and constraints impinge on them. It asks who bears the costs or benefits from strategies in which individual interests or needs are often subordinated. A focus on family strategies reintroduces a problematic, an intentionality and uncertainty in history, without abandoning systematic analysis. It moves away from, on the one hand, any implicit acceptance of the powerlessness of people caught up in a process of large scale structural change, or, on the other hand, the attempt to see into people's minds, to study mentality or attitude, which can be tautological. (As, for example, when people's attitudes are deduced from their behavior, and then their behavior is said to be caused by these attitudes.) The concept of family strategies works as a series of hypotheses about "implicit principles," as Pierre Bourdieu (1976:141) puts it, less rigid or articulated than decision rules, by which the household, not the individual or the society as a whole, acts as the unit of decision making.

There are family strategies for dealing with migration, fertility, schooling, labor force participation, coresidence of children, even age of marriage. These strategies have different effects on individuals, depending on their position and activities in the family. All household members' imperatives and choices are shaped by their position in the family, by the economic and social structures in which the household is located, and by the processes of change which these structures are undergoing. Strategies, as analyzed by Bourdieu, tend to reproduce social relations. When circumstances are changing, however, strategies can change, too. Whether, how, and when they change are the important questions. Analysis of household and family strategies addresses social behavior in the past at a level where analysis is meaningful; it examines decision-making principles which are voluntary, problematic and yet identifiable. Finally, the concept of family strategies is applicable both to individual biography, to the degree that other family members and family interactions are discussed, and to collective biography. Systematic comparisons between the two levels can be mutually enlightening (see Laslett, 1978).

This paper applies this prescription for historical research to the history of proletarian women, their families, and their 
work in France from 1870 to 1914 . The word proletarian is used here in the sense of persons who work for wages and own no capital. In France as in most of Europe, much proletarianization, on-going for centuries, was rural. Peasants lost their small holdings, or their holdings were subdivided to such a degree that they could not support a family with their agricultural product. In some areas, rural proletarians survived by working in cottage textile industry, producing cloth in their own small houses for urban merchants and their agents. In other places, rural proletarians worked as wage labor on large scale farms. Over the course of the nineteenth century, cottage production of textiles was driven out of existence by competition from large scale factory industry. Rural weavers, their textile wages pushed to starvation levels by urban competition, either supplemented these wages by other work or abandoned their villages and migrated to industrial cities.

The two cases examined here lie at two extremes of proletarian experience. In each case two kinds of questions are asked: how did family strategies cope with and reflect the circumstances of proletarianization? and what were the consequences for women in these families? These questions will be examined for several specific strategies, viz., marriage, fertility, schooling, and labor-force participation. The organization of work and changes in it are the essential context for the analysis of these strategies.

The concept of strategies implies objectives. What objective did the families examined pursue? Quite simply, they strove to promote nuclear family survival over the cycle of family expansion and contraction, from marriage of the couple, through child bearing, child departures, return to the solitary couple, and death of its members. It was this goal which informed family responses to economic structure and change, to political interven- tion in or impact on their adjustment to economic realities. How families pursued this goal differed, then, according to both structural and historical factors.

In nineteenth-century France, an adult male usually acted as agent for the family in the public sphere, such as relations with employers and the state. This was true even when, as illustrated in the autobiography of Mémé Santerre (Grafteaux, 1976:34), his literate daughter kept a record (for the purposes of checking the paymaster's totals) of the work the family did. What the adult male role was in private decisions, such as those about fertility and family size, is simply not known. In this paper, families are conceived of as acting in a unitary way to make decisions. The behavioral consequences, whether positive or negative, of strategies for individual family members, rather than their presumed role in making decisions, are examined in the conclusion.

One type of family strategy is illustrated by the behavior of the rural farm laboring weavers from the village of Avesnes-lesAubert, near Cambrai in the department of the Nord. These people were called Camberlots, after the chief city of their region. Their lives were shaped by their work as domestic weavers in a period when the industry was being undermined by the growth of a large-scale textile industry. As their livelihood became more and more precarious, the villagers sought other means to support their families. There were jobs for workers in the nearby sugar beet fields, so the first adaptation of the Camberlots was to supplement weaving with farm day labor in the Nord. The subprefect of Cambrai, in his responses to the national "Enquête industrielle" of 1873 (ADN M 605/4), noted that subdivisions at succession had led to an increased number of tiny farms and landless laborers. Both former peasants and weavers sought work in the sugar beet fields. The combination of agricultural work and weaving 
produced, he wrote, "very fortunate conditions which visibly increased their wellbeing."

Within a few years, however, official reports were less sanguine. In 1878, an "Enquête" on the condition of weavers in the Nord (ADN M 581/141), said that "In the arrondissement of Cambrai in particular, handloom weavers are being replaced by machines-and they must find other ways to live. . . . in general, the workers received barely two-thirds of what they need to buy bread, not to speak of housing or clothing. ..." Another report notes, "The workers understand what is happening, and they don't struggle against events; some of them have emigrated, others work in the fields; unfortunately, the population is too dense for agriculture to support their needs, but most of them stay because they own a little house and are certain they can't find a job elsewhere." This opinion, that workers accepted their fate, proved to be wishful thinking. In 1886, some 90 percent of the workers in Avesnes-les-Aubert were employed in the textile industry. In February 1889, and in June 1895, there were weavers' strikes in Avesnes; the cause, according to the police reports, was inadequate wages (ADN M 619/7, M 625/67; AN F 12/4665; Perrot, 1973: $113,358-359,570,581,585)$.

Abel Chatelain (1977:679-680, 686691), in his study of temporary migrations in France, shows how conditions in the Cambrésis continued to change in the 1880 's and 1890's. First, sugar beet and then chicory cultivation came into the Nord. These commercial farmers brought their own workers, Belgians who had already worked for them in their native country. The Camberlot farm laboring weavers, denied employment in agriculture nearby, followed the cultivation of the sugar beet to Normandy and the Paris region, about one hundred miles away. This adaptation delayed the final collapse of the domestic linen weaving industry.
Ironically, then, the Camberlots moved from work in manufacturing into agriculture, albeit capitalist agriculture. This Camberlot way of life was an adaptation to specific circumstances in the Nord. It was a case of people preserving an old way of living-weaving linen in the cottages of Avesnes-through adaptations which continued, for many, until the First World War broke the back of the domestic weaving industry.

The autobiography of Mémé Santerre (Grafteaux, 1976) tells about three generations from Avesnes-les-Aubert: that of her mother and father, born in 1848; that of Mémé, their youngest child, born in 1891; and that of her son, born in $1911 .{ }^{1}$ Other materials from French municipal, departmental, and national archives provide systematic evidence on the demogra-

'Serge Grafteaux, Mémé Santerre (Verviers: Marabout, 1976). This life story was told to a journalist by Marie Catherine Santerre in 1974, at which time she lived in an old people's home in Meaux, near Paris. Her doctor had been impressed by her stories of her life and told his journalist friend about her. Telling her life story was useful to the woman in dealing with the death of her husband and facing her own remaining years of life. Her stories about her early years are particularly vivid and clear. I tried to verify her memories by going to the municipal archives of Avesnes-les-Aubert, the Departmental Archives of the Nord, for demographic and social information about the village from the 1870's to 1914. My check of the dates in the autobiography revealed that Mémé Santerre usually had her own dates correct. She was inconsistent about how long she spent in school, and I was unable to check that record. She gives her mother's year of birth as 1841 , by several mentions of her age at dates which can be internally checked by events. This would have made her 50 at the birth of her thirteenth child. The birth register for Mémé, born in 1891, and of the registration of her marriage in 1909 show her mother's year of birth as 1848 , which fits with the timing of events in her life better than the earlier date. Méme Santerre's death is entered in the register next to her birth. She died 14 February, 1977, in the old people's home in Meaux. See Dufrancatel (1978:149-151) for a cautionary opinion about Grafteaux' motives in publishing this autobiographical piece. 
phy, economy, and collective action of the people of Avesnes-les-Aubert.

A different type of family strategy is illustrated by examination of the residents of Roubaix, an industrial city also in the department of the Nord, about forty miles from Avesnes and Cambrai. Roubaix had been an important cotton textile producing center since the 1820 's. In the 1860 's, the city boomed as a center of factory textile production, based by then on wool rather than cotton. It was not a "typical" French city, but it shared many characteristics with other textile cities. Belgian migrants were attracted to the rapidly growing city at the end of the nineteenth century, migrants from areas of Belgium where domestic weaving was in a disastrous decline similar to that around Cambrai (Reardon, 1977; Lentacker, 1950). Migration to Roubaix was not seasonal. Yet it was probably temporary for many migrants, and initially considered temporary by many others, who later became permanent migrants. Thus migration to Roubaix and factory employment was another possible adaptation of families whose livelihood in the domestic textile industry was being destroyed. Rather than sharing manufacturing and agriculture, as did the people of Avesnes, all the while continuing to be proletarians, migrants to Roubaix moved to the prototypical industrial setting-a factory textile city.

The chief source of evidence for Roubaix is a machine readable file of a systematic sample of all individuals in ten percent of the households drawn from the national censuses of 1872 and 1906. Family relationships and labor-force participation, as well as individual characteristics (age, sex, marital status) for individuals within households, household residence patterns, and other characteristics have been analyzed. Other material about Roubaix includes archival, newspaper, and secondary information on housing, wages, prices, material culture, work process, in- stitutions, and collective action. ${ }^{2}$

We turn now to an examination of women and family strategies in the two cases: that of the Camberlot farm laboring weavers of Avesnes and that of the industrial workers of Roubaix. Both cases concern proletarian workers in France, but each case produced a different set of strategies and adaptations. Each case also has its own type of sources. The individual autobiography, illustrative of the Camberlot way of life will be used for comparative insights on which collective biography is silent. The conclusion returns to women's lives and to family strategies in their broad outline and examines the consequences of the latter for individual women over their life cycle.

\section{Mémé Santerre and the \\ Camberlot Way of Life}

Here is Mémé Santerre's description of her family's work life (and that of other village families) near the turn of the century (Grafteaux, 1976:10-11).

The village men didn't like to have their wives away from home. They needed them in the cellar. . . There in the big half-dark room, lit only by several high windows, were the looms on which everyone in the village wove during the winter months for eighteen hours each day.

After my time at school-being the youngest, I was given the chance to go ... I too had "my loom." I was still so tiny when I first wove that I had to have wooden "skates" attached to my feet so I could reach the

${ }^{2}$ The Roubaix material is part of that gathered for a larger research project comparing work, family, and collective politics in three French cities, 1870 to 1914. Three papers based on this material are Tilly, 1978; Tilly, forthcoming; and Tilly and Dubnoff, 1978. Research support was provided by the Rockefeller Population Policy Program, 1974-1976, by the Rackham School of Graduate Studies, 1976-1977, and by an American Philosophical Society Grant, 1977-1978.

The condition of the hand-loom weavers of the Cambrai region is discussed in Charles Blaise, Le Tissage à la main du Cambrésis. Etude d'industrie à domicile (Lille: Bigot, 1899), and E. Simonet, "Chez les tisserands du Cambrésis," L'Echo du Nord, 12-16 September, 1906. 
pedals. My legs were too short to reach them. ...

At four a.m. we awoke. Dressing quickly, with water from the court fifty meters away, where a well served all the families in our coron [an attached row of houses], and hop! we went down to the cellar with two coal-oil lamps. During this time, my mother lit the round stove that heated the main room. . . she called us, at around 10 , to come upstairs and get our "coffee." It was a long time to wait after waking before we got this hot drink that seemed delicious to us. . . My sisters and $I$, we made handkerchiefs that we wove into big rolls of linen. My father, who was more skillful, made the wider pieces of linen. . . himself.

Every Saturday, one after another, running, because we wished to waste as little time as possible, we would take our cloth to the agent, an inhabitant of the coron like us, who collected the work, and got the money for it.

... I would return home and give the money to my mother. Then my sisters would go, then papa, to take their work.

We couldn't make ends meet with these earnings. We had to live all winter on credit. We paid up on our return from the season in the country, which took us away from home for six months, to a farm in the SeineInférieure.

From May to November each year, the Gardez, Mémé's natal family, worked on the farm in Normandy. Here Mémé describes the work on the farm (Grafteaux, 1976:25-26, 29).

The domaine of Saint-Martin, where we worked, produced only wheat and sugarbeets. It belonged to a big company in Paris which owned farms throughout France. We were paid by the job, such as, for the harvest. The more one did, the more one earned. And each family member had his or her ailocation of land.

...We were paid all together when we left in November, a large quantity of money such as we never otherwise saw at one time. ...

That year, as others, our moving-in accomplished, we set to work at 6 a.m. We could see the size of the farm; fields rolling to infinity; in early May the fields were covered with fine green sprouts. Fields of wheat undulated further out, and those were the fields we worked in first, to pull out the thistles. .. .

It was hard work, however, for a little girl! When I saw the parcel that had been assigned to me stretching out, it seemed as though 1 would never arrive at the end, for the rows were long...

When one arrived at the end, one had to turn immediately and make one's way back, standing upright as little as possible. . . .

Later... we had to thin the sugar beets. Interminable furrows where we left the strongest and best-centered plants so that the row would be straight as the letter I.

Each row brought us three sous. We could do up to four in a day, if we didn't fool around or look at the flies in the process; we worked bent constantly over the furrow, a foot on each side and a short hoe in our hands.

How did the families of Avesnes behave within these brutal work regimes? How did family strategies affect the lives of Marie Catherine Gardez, born in 1848, and of her last child, Marie Catherine (Mémé) Santerre, born in 1891? Mémé's autobiography shows that despite brutalizing work and poor living conditions, these women led lives of dignity in which they enjoyed and bestowed love and respect. Love, anger, resentment, hope, disappointment, luck, character, political vicissitudes like war all affected the family lives of the Gardez and Santerres and the other Camberlots. Focusing on the effect of work on family strategy provides a means of understanding much of their behavior, but not all of it. It helps us examine that part of the lives of these families, and of the other villagers, which was governed by the obligation of their families to sell the labor of several members in order to survive. At the same time, using autobiography helps us realize that the material realities of the poor are not such powerful constraints, that emotions and feeling are not brutalized or absent. Autobiography can contribute to an analysis which allows us to interpret the collective behavior, individual behavior, and feelings of ordinary people in a holistic way. One conceptualization of this need is the "way of living," which E. P. Thompson (1977:501) notes, "not merely a way of surviving, but also a way of relating and valuing." $\mathrm{He}$ continues, "For the vast majority throughout 
history, familial relations have been intermeshed with the structures of work. Feeling may be more, rather than less, tender or intense because relations are 'economic' and critical to mutual survival."

Here, briefly sketched, are the life stories of the two women. The elder Marie Catherine was illiterate; she married young, and she and her husband set up a new household; they had 13 children. As the children grew up, they were set to work each in turn at the looms in the cellar and in the fields of Normandy. The daughter, Marie Catherine, went to school for four years before she joined her sisters and father in the cellar. She married at 18 and set up a new household with Auguste Santerre, a farm laboring weaver like her father. After 1914, they stayed in Normandy, becoming full-time workers on the farm and in the sugar beet refinery. They had only one son, whom they sent to school and apprenticed. He left home to follow his occupation and eventually married. Mémé and Auguste, his parents, later moved (although continuing to work for the same large agricultural firm) to live near their son. This brought them to the Paris region, where all three finally died.

Let us look more closely at family strategies in the Gardez family of Avesnes-lesAubert and of the other villagers in the last quarter of the nineteenth century.

In this period, fertility was high in the village of Avesnes-les-Aubert. Mémé Santerre believed that most families in their coron had at least ten children. She also notes that many families took six or eight children to work in the fields. Her own natal family had 13 children, her husband's at least $11 .^{3}$ The number of children under five per ever-married woman

\footnotetext{
${ }^{3}$ Grafteaux, 1976:24, 51. The autobiography notes that Auguste was the oldest of nine children; the census list for Avesnes-les-Aubert in 1906 (ADN M 474/38) lists eleven Santerre children, the last born in 1906 .
}

aged 20-49 for the village, calculated from the 1886 census summary (ADN M 473/ 33 ), was 1.3 , extremely high.

Apparently, families in Avesnes were doing little at the end of the nineteenth century to restrain their fertility, despite the poverty in which they lived. For them in fact, children could be a solution to their poverty, for multiple wage earners in a family were the most certain route to an adequate income at some time in the family cycle. Nevertheless, many years had to pass before children could contribute to family income, and those years could be difficult years for the family economy.

As the children grew up, parents waited anxiously for the moment when they could become wage workers. They did not invest in their children's futures by sending them to school. Both Marie Catherine Gardez and her husband Pierre were illiterate. None of their children born in the 1870 's and 1880's went to school. The 1873 "Enquête industrielle" remarked that only about one-quarter of the adult manufacturing workers in the arrondissement of Cambrai knew how to read and write. Mémé, the last born, went to school for four years, but her older brother and sisters had been needed as workers on the looms in the cellar of the cottage and in the fields. This alternating pattern of work kept the children busy year round, and left no "dead season" like that in settled agriculture, in which the children could attend school. ${ }^{4}$ Even in the 1890's, weaver families apparently continued to act according to a similar short-term strategy, and Mémé's school attendance may have been a consequence of her birth order rather

${ }^{4}$ See Furet and Ozouf, 1977:258, for comment on the damaging consequences of year round employment in industry for children's schooling. The "Enquête" of 1873 (ADN M 605/67) notes that among the agricultural populations around Cambrai, "progress" had occurred in instruction, but "a large number of children only attended school in the winter." 
than changed strategy. Auguste Santerre, later to be Mémé's husband, was born in 1888 , the oldest of 11 children in an Avesnes family of farm laboring weavers. He did not get any schooling, despite the compulsory free schooling decreed by French law in 1884. Until parents had the extra income provided by several child workers, they did not send children to school.

The other side of lack of schooling for children was their early labor-force participation. We don't know at what age Mémé's mother, Marie Catherine Gardez, started to weave with her parents, but it was probably very early. In 1873 , the "Enquête industrielle" (ADN M 605/4) noted that 20 percent of the industrial labor force of the Cambrai arrondissement were children. In the 1895 strike in Avesnes, 37 percent of the striking workers were children (ADN M 625/67). The Gardez children all descended to the looms in the cellar of the cottage in Avesnes by age 8 to 10 . The last born child, Mémé, started to weave when she was ten. She notes that her father criticized families who took their five and six year olds into the fields. He said, she writes (Grafteaux, 1976:24), "There is a time for everything in life. Just because you yourself started work early with kicks in the behind, you don't have to press your own children the same way." He felt that it was early enough to start field work at 11, which is what he did with his children. Early labor-force participation was part of the end of the century pattern in agriculture as well as industry.

An illustration of the fragility of high fertility strategy occurs in Mémé's story of her parents (Grafteaux, 1976:16-15). In 1871 , the Gardez were a young couple with three children under five. Pierre was called to serve in the Franco-Prussian War, and a tragic drama ensued. Marie Catherine, pregnant with her fourth child, was not able to weave enough to support herself and three little children. The infant she gave to a neighbor to mind died due to the baby-sitter's carelessness. The two girls died of illness. When her husband heard the news of his children's deaths, Gardez. ran away from his regiment, and returned home-to weave. He flung himself into the cellar like a madman and vowed that he would not leave until he had woven enough cloth to support his wife through the birth of their fourth child. The military police who came to take him back to his unit respected this need and let him stay home to finish the work. The couple"s division of labor required the husband's labor, and wages, to support his wife in her childbearing years when there were no children old enough to work.

The French census takers in 1906 listed no occupation for Marie Catherine Gardez when they came around to the weavers' cottages that year. Yet Mémé testifies (Grafteaux, 1976:11) that her mother did vital tasks:

\footnotetext{
Mama tended to the housecleaning, scoured the floor, scraped the table with a shard of glass, threw fresh sawdust on the tiles, and boiled potatoes, and at the same time prepared the warps that we would weave the next day.
}

Madame Gardez did not receive a separate wage-only the weavers did; they were paid for each piece of cloth they took to the merchant's agent. They immediately handed their wages to her, the wife and mother, to spend for the consumption needs of the family. This was true of her husband as well as of her daughters. There was no surplus for the head of the household to spend on his personal leisure or pleasure. The family, in fact, lived most of the winter on credit for their very bread; they only paid the baker on their return from the season in Normandy.

In the weaver's cottages, husbands, wives, and children made vital contributions to the family economy. Since there was no surplus, there was little inequality 
in distributing it. When the family did not go to Normandy, in the last summer before Mémé's marriage, everyone restricted consumption further, and worked harder. The family ate no meat whatever; they repaired their shoes with bits of leather from the harness of their looms. Mémé remarks (Grafteaux, 1976:48) that it was hard for the children to understand. "But did we ever understand? We spoke so little among ourselves. There was no place in life for words. Our fixed, our only goal, was to eat, sleep, and work."

Although couples had many children and valued them as workers, nevertheless grown children tended to marry young in Avesnes-les-Aubert (cf. Levine, 1977; Braun, 1966). Marie Catherine Gardez and her daughter Mémé married at 18 or earlier. (Marie Catherine Gardez' age of marriage was deduced from the fact that at 22 , in 1871 , she had three children and was about to give birth to a fourth.) Both women set up households apart from their parents. The older couple also apparently lived in a village in which they had no relatives to help them, for the mother had to go to a neighbor for assistance for child care in 1871. Mémé lived close to her mother-at her birth her brother had declared to the parents that this daughter would be a "crutch in their old age." She benefited from her mother's warp-making even when she was married and weaving with her husband in another cottage. The grandmother also cared for Mémé and Auguste's little son while they wove, and for the entire summer season when the younger couple went to Normandy. The older Gardez children, born in the 1870's and 1880 's, also married and left home early. In 1906 (ADN M 474/38), only four unmarried sisters were at home, ages 14 (Mémé herself), 17, 18, and 20, according to the census. Mémé's sisters had married young. The first child of her sister Zulma was born when she was 17 ; the first child of her sister Lucie had been born when she was 19; and the first child of her brother Leandre was born when his wife was 20 (ADN M 474/38). Four other older sisters no longer lived in Avesnes; they had married farm laborers and lived elsewhere in the region. The census age, sex, and marital status summaries for 1886 (ADN M 473/33) make it possible to calculate proportions of single people in various age cohorts in the village. These confirm a pattern of early marriage and little celibacy: only 50 percent of women aged 20 to 24 were single, 28 percent of those 25 to 29 , and three percent of those aged 50 to 54.

The family lives of the Gardez family and their neighbors in Avesnes-les-Aubert reflect the organization of their work as weavers and the web of opportunities they followed to find supplementary work as the domestic textile industry declined. They sought to maximize their children's labor and contribution to family subsistence and the family's future. They had many children and did not send them to school. Yet the fact that the productive unit was still the household led to early marriage and relatively short coresidence of adult unmarried children. In the weaving period of their yearly work cycle, daughters received individual wages; in the agricultural labor phase they received no individual wage. Neither the family wage nor the household productive unit kept the family together, however. Just the contrary: there was a limited number of places in that household unit. With their four looms, they could keep only four workers and a helper occupied at one time. As younger children took their place at the loom, older children moved on to find work. Sometimes they moved, as servants, into a situation of dependency resembling their position in their household of origin. Sometimes they married and formed a new household in order to work in weaving or agricultural labor (cf. Rapp, 1978:90-91). The consequence of the continuation of a 
family wage and a household productive unit was an early break away from family of origin to set up a new family of procreation.

\section{Industrialized Roubaix and Roubaisien Workers}

With the mechanization of wool combing and weaving in the 1860 's, Roubaix completed its industrialization. "At the end of the Empire [1870]," Claude Fohlen (1956: 339) writes, "Roubaix possessed ten thousand mechanical looms, about half such looms in France." Most workers after 1870 were employed in large mills at whirring machines powered by steam. Work hours went from 5:30 in the morning to 7:30 in the evening in the summer, 7 a.m. to 9 p.m. in winter, with a two-hour break for lunch. According to the census of 1872 , more than 50 percent of the labor force was employed in the textile industry. Almost half the textile workers were female, mostly unmarried girls: 81 percent of single females (over 15) worked, but only about 17 percent of married women. ${ }^{5}$

Roubaix was flooded by migrants from Belgium and the French countryside in the 1860's. Housing was scarce and crowded. Courts and various types of brick row housing were built, but they were inadequate for the numbers of new residents arriving. Larger tenements were no better. "The interior court common to all was a receptacle for sewage, for stinking water which could become the source of pestilence. ... An air of misery and abandonment reigned throughout," wrote a visitor (Reybaud, 1867:208) to the Fort de Roubaix in the 1860 's.

How did families in Roubaix cope with these conditions of work and life?

Fertility was high in Roubaix, just as it

${ }^{5}$ These figures and all other analyses of Roubaix statistics, unless otherwise indicated, are calculated on a ten percent sample of households in the 1872 and 1906 census nominal lists. was in Avesnes. Crude birth rates continued in the high 30 's per thousand through the 1880 's-in 1886,36 per thousand. The ratio of children to women in 1872 was .86, lower than that of Avesnes. This figure reflects not simply births but infants who have survived up to five years of age. Infant mortality (deaths of children under one per 1000 births) in Roubaix in this period was consistently over 200 (Felhoen, 1906:12). Thus, the Roubaix child/ woman ratio, already high, understates fertility. Apparently, Roubaix proletarian families were acting in ways similar to those in Avesnes as far as fertility was concerned, for their children could also be workers while quite young.

They acted similarily also regarding schooling. Roubaix parents, like those of Avesnes, were themselves likely to be illiterate. The mayor of Roubaix noted (Rapport, 1864:7) that in 1863 , only 29 percent of brides could sign the marriage register. He continued that this was not surprising, considering the fact that "a great number of the marriage partners were born in Belgium, from which they arrive, deprived of any instruction, to seek jobs. ..." The brides were less likely to sign than their grooms. The men's rate of signature ( 44.5 percent), when compared to the literacy of the men called to military service that year ( 62 percent), showed the grooms to be less literate. This suggests a connection between migrant status and illiteracy, for those called to military service were native-born men. The following year the mayor's report (Rapport, 1865:6-7) analyzed marrying persons by place of birth (but not by sex), and found that 45 percent of the French-born had signed the act, but only 26 percent of the Belgian-born. Furet and Ozouf (1977:257-260) show a decline of literacy, as measured by ability to sign marriage registers, in the industrial arrondissements of the Nord, since the urban school systems were overwhelmed 
by the children of migrants. The marriage rolls were filled by illiterate adult migrants marrying in the city.

Only 35 percent of children under 15 who lived in Roubaix in 1872 were in school. Migrants to the city were acting like seasonally migrating weavers in agriculture. They were not investing in their children's futures by sending them to school, for their children could find unskilled year-round jobs when quite young at relatively good pay.

In Roubaix, boys and girls did wage labor in 1872, just as the Gardez children of Avesnes. Of children aged 10 to 14, 38.9 percent of girls and 36.5 percent of boys listed occupations in the census that year. Migrant families, recently arrived in Roubaix from areas in which they had been weaving in domestic production, continued to see the household as a wageearning unit, even though it had ceased to be a productive unit. Migrant families in Roubaix needed the multiple wages of several family members in order to make ends meet. In most families, children over ten became wage earners in preference to their mothers, who were more likely to stay home (Tilly, forthcoming).

Wives worked most commonly when there were no children in the household. Nevertheless, there were wives who did wage labor in Roubaix in 1872 even when there were children under five in the household, because this period when most of the children were very young, was the time of greatest need for the household. Children were then consumers of goods but contributed no wages. This was the family-cycle poverty squeeze, which has already been noted in the family history of the Gardez. Wives in the industrial setting of Roubaix found it even more difficult to work for wages at this moment because of conflicting demands at home. Families needed wives' wage work when the ratio of consumers to workers was high-that is, when there were small children in the fam- ily. Employers' preference for young workers meant that a young wife could find work more easily than an old one. Nevertheless, it was primarily wives of illpaid and unskilled men, or mothers in families where the male head was unemployed, who worked at this stage. Young wives with several young children at home were less likely to work than those with only one. Those wives with children under five who did wage work had heavy responsibilities at home and in the factory, and the contradictions in their situation were so strong that families were unlikely to see much benefit in such wage labor except in situations of real necessity.

Among young wives (15 to 25 ) in Roubaix households in 1872,35 percent listed occupations, while only 8 percent of those 50 to $60 \mathrm{did}$. If we look more closely at the older wives, another characteristic of Roubaix family life becomes evident. This is the large proportion of households headed by older women. Of women aged 50 to 60 living in multi-person households, 24 percent were heads of household in 1872. These female-headed households were due both to high adult male mortality and to the migration of single parent households to the city where children could work. The household productive unit of the weaving village required an adult male member, but a household which sent its workers out to factory work did not. These family economies were likely to be fragile, as indicated by the fact that more wives worked in female-headed households than in two spouse households. Thus an important contributing factor to older wives' labor-force participation was their responsibility as heads of single parent households.

In Roubaix, 1872, age of marriage was later than in Avesnes and spinsterhood was more common. Sixty-seven percent of women aged $20-24$ were single and 33 percent of those aged 25-29. Over 12 percent were still single in age group 50-54. 
Children by and large lived with their parents until they married, but once married, they seldom lived in their parents' household. Of female children aged 15-19, 86 percent lived with their parents in 1872 as did 45 percent of those 20-24. Only 2 percent of the women 20-24 living in their own households were not wives themselves.

Thus the availability of individual wages for young people and the separation of work place from residence did not lead to a period of autonomous living in most women's lives. The coresidence of adult children in their 20's with Roubaix parents offers a strong contrast with the situation in Avesnes. But it should be noted at the same time that the young women of Avesnes who left their parents' household did so not for any independent living arrangement but to enter another household through marriage.

In Roubaix in 1872, as in Preston, Lancashire (1851) described by Michael Anderson (1972:233-234), there was an apparently successful family effort to keep children in the household, working for the family wage fund. As Anderson suggests, and as our comparison of Roubaix with the fragmentary evidence for the Avesnes weavers corroborates, parents and children lived together longer in the textile city than in agricultural or weaving villages.

Why did Roubaix adolescent and young adult children reside with their parents? Part of the explanation lies in the fact that wages of children under 15 were very low; children could not afford to live alone. Families also had advantages to offer older children whose wages might be higher. Housing itself was in short supply in Roubaix. Factory jobs provided no housing, as did service or agricultural labor jobs. In working-class households, wives provided services for their employed husbands and children. Kin networks facilitated migration, and kin or neighborhood networks helped people find jobs or gave aid in times of need. These family- linked services could only be enjoyed by coresident children.

\section{Change}

Matters changed very little in Avesnes before World War I. Fertility had declined somewhat and more children were in school. Yet evasion of school and child labor laws was hard to control in domestic industry, so this legislation was not effective among weaver families in Avesnes. The tragic and dramatic shock of the First World War hit the weaving village in August, 1914, when many villagers were away in Normandy during the seasonal migration. Many others fled the advancing Germans. The Monument aux Morts for the War of 1914-1918 in the village square is dedicated to the dead of Avesnes: 155 military, 7 civil victims, and 1630 victims of the evacuation. Some 36 percent of the villagers died in the war. Others, like Mémé and Auguste Santerre returned only to find their house occupied by someone else, their relatives dead and dispersed, the weaving industry definitely destroyed. The Santerres, their son, and Auguste's parents returned to Normandy to work on the farm year round.

In Roubaix, change had started earlier and was more gradual. Family strategies changed as the economic and political situation changed.

Starting in the late 1880 's, fertility began to decline in Roubaix. By 1906 the ratio of children to women was half that of 1872; the crude birth rate had dropped to 21.5 per thousand. Family strategies had changed in response to compulsory schooling, child labor laws, changing technological demands of the textile industry, and more importantly, better real wages for men and, consequently, reduced need by households for child workers. There were much smaller proportions of children 10 to 14 with reported occupations: 15 percent for girls, 10 percent for boys. Families were investing in their children by 
delaying the age at which they began wage labor and by sending them to school longer.

Roubaix increased the number of its schools in the late 1880's and 1890's to bring the city into accordance with the new national compulsory education laws. By the end of the century, its population was more often urban born, and the short term "work, not school" strategy was no longer the rule for Roubaix families in 1906. Seventy-eight percent of the children under 15 in Roubaix were in school in that year.

Many more wives worked in 1906: 31 percent total average, 57 percent of very young wives 15 to 25 , and 22 percent of those 50 to 60 . The young wives who lived with their husbands and also worked had on the average half the number of children of those who stayed home, and they were much less likely to have a child under five. Fewer children, born in less rapid succession, were characteristic of the families of young worker wives. The proportion of women aged 50 to 60 who were heads of multi-person households stayed about the same-23 percent. The proportion of older wives who worked in these female-headed households had increased to 64 percent. An equally dramatic increase had occurred in the number of older wives working in husband-headed households (15 percent). These older working wives had much fewer children than stay-at-home wives of the same age and status-an average of 1.3 as compared to 2.2. They had no children under five and many fewer of their coresident children were working- 0.8 as compared to 1.5 for non-working wives of the same age. Wives were spending more of their lives as wage workers in Roubaix in 1906 , to the benefit of their fewer children who spent more time in school and entered the labor force at a later age. In 1906, the family strategy of labor force allocation was sending wives to work rather than children. Nevertheless, there were similar patterns of children in residence with their parents in 1906 and 1872. The number of years of their lives in which mothers had coresident children had not changed. Combined family members' wages were still needed to keep families above the subsistence level (Tilly and Dubnoff, 1978). In these families, the mother's contribution of services provided the margin for the children's and the father's expenditure for leisure or savings.

The increased proportion of young females who lived in their own households in Roubaix in 1906 as single women, not wives, was part of the large pattern of demographic change in the city. Sex ratios in the city had dropped sharply since 1872 . The male to female ratio of the sample was 109 in 1872,92 in 1906. Female nuptiality had declined. Seventy-five percent of women 20 to 24 were single, 42 percent of those 25 to 29 , and 19 percent of those 45 to 54 . By 1906 , there were many working women in Roubaix whose lives were not affected by the strategy of the family they lived with, because they did not live with their own families. In the 15 to 25 age group of working women, these amounted to 3 percent living in single person households, 12.5 percent living as lodgers, servants, or other non-relative position in other households. Among working women aged 50 to 60,8 percent lived by themselves, 4.7 percent with non-relatives. The relatively sharp separation of home and work place in Roubaix, 1906, the low sex ratios of the city, and the availability of better individual wages meant that some women were living on their own, apart from their families. Their numbers were quite small, but the proportion is notably higher than in 1872 . Whether these women's independent lives were the consequence of independence of family strategy, defiance of family strategy, or acceptance of family decisions which sent them out of 
the household to migrate on their own to the city, we cannot know with the evidence at hand.

\section{Conclusion}

Just as there were varieties of proletarianization in nineteenth-century France, so in turn were there different family strategies and patterns of behavior. In Avesnes-lesAubert, the Camberlots began an arduous seasonal migration in agricultural labor when local opportunities for wages to supplement their sub-subsistence weaver's earnings dried up. Wage earning families on the sugar beet farms of Normandy continued weaver family strategies: low age of marriage; formation of a new household productive unit on marriage; high fertility; high labor-force participation by children.

Migrants from areas of domestic industry who moved to an industrial city with wage-earning opportunities for women and children modified their family strategies in rhythm with changing patterns of opportunities in the city. At first, fertility was high and children were put to work early. Since formation of a new household was not a prerequisite for production, however, there was an effort to keep children home with their parents, working and contributing to that family economy. With time, child labor became less common in the city; some schooling was enforced by law. Although fertility declined, control over children was still the goal of parents, who prolonged their semi-dependence through coresidence. The services that mothers provided their unmarried, coresident adolescent and adult children were an important factor in the continued coresidence of those children.

Women were entwined in family strategies in both Avesnes and Roubaix. It is hard to apportion the costs of family strategies in Avesnes-les-Aubert among the individual family members. Everyone in the family was a victim-working grueling hours, eating minimal diets to make ends meet. Mothers bore many children; their daughters worked hard as children (as did their sons) and then moved into a parent/worker role. A woman whose husband did not drink or spend sparse family earnings on his personal leisure probably spent about the same amount of time working as he did, and endured about the same amount of physical strain in a relatively equal down-trodden position.

In Roubaix, more alternatives emerged for families in time. Mothers and children suffered the brunt of family strategy when high fertility and multiple wage earners were the family adaptation. In the later period, the sacrifice of children was attenuated. The cost to mothers changed form but did not disappear. By 1906, women had fewer children so they had fewer childbearing and child-care burdens. Married women then were more likely to do wage work, however, so their leisure did not increase. Children were less the victims of family strategy, more often the hope of that strategy. But mothers bore the costs of their children's and their husband's leisure, and of whatever saving they did.

Women who lived with their natal families as daughters in 1872 or 1906 benefited to some degree from coresidence. Any benefit, however, came at the cost of their mothers. These daughters submitted to some family demands, for at least part of their wages, for the delay in their marriage. Single women living on their own are an enigma. In Avesnes, there were practically none, as was the case for Roubaix in 1872 . By 1906, however, there were many women of all ages living in the textile city on their own. Here an autobiography could help us understand what kind of lives they led, since the census is silent.

In closing, I return to the question of interpersonal relationships of parents and children in a situation which could be called child-sacrificing. Mémé Santerre provides insight here. In fact, she offers 
two clearly contrasting cases. Her parents were tender and caring about their children even as they involved them in the same exploitation of which they themselves were victims. The father insisted that the girls take a break in their weaving day and walk outdoors; the parents carried their exhausted daughters to bed after the backbreaking days in the sugar beet fields. Mémé Santerre fondly recites the gay, romantic songs her father sang to keep their spirits up. The father made his daughters little treats-tiny loaves of bread-when he baked the family's large loaves. The parents celebrated holidays and life transitions, like first communion, with special food for the children-an orange, a bit of meat for dinner. Quite a contrast to the piles of cream puffs at the communion feast described in a bourgeois autobiography (Motte, n.d.:10-11) from Roubaix in the same period, but nonetheless sharing the same spirit of celebration of children's passage to adulthood. Mémé's marriage involved sacrifice on the part of her parents, but they indulged her, as their youngest child. This indulgence was made easier by the fact that her two older sisters were still at home when she married, wearing her mother's worn silver wedding band.

Life was not so full of concern and love in all Camberlot families. In his late teens, August Santerre was in constant conflict with his parents. His father beat him and tried to prevent his marriage. As the eldest son in a family, with ten children behind him, his wages were vital to the family, and his father claimed them with violence. These difficult times passed, and father and son were reconciled when a grandson was born, despite the son's earlier defiance of his father's wishes. Families who were pursuing similar strategies could be characterized by entirely different emotional climates.

The Gardez and Santerre families, though they acted in patterned ways simi- lar to their covillagers, were made up of individuals, as were the Roubaisiens. As this paper shows, labor market conditions and productive systems influenced the strategies of families in which these individuals lived. Important as the family was as a mediating structure with the economy, there was a space in the lives of individuals in which caring and valuing-or hating-were to be found.

\section{BIBLIOGRAPHY}

Anderson, Michael

1972 "Household Structure and the Industrial Revolution. Mid-Nineteenth Century Preston in Comparative Perspective." In Peter Laslett and Richard Wall, eds., Household and Family in Past Time, 215-235. Cambridge: Cambridge University Press.

Archives Départementales du Nord (ADN)

M 473/33. Census Summary (1886).

M 474/38. Avesnes-les-Aubert Census (1906).

M 581/141. Enquête sur la situation des ouvriers tisseurs de département [Nord] (1878).

M 581/141. Minute of Perfect of the Nord (May 8, 1878).

M 605/4. Enquête industrielle. Report of Subprefect of Cambrai (1873).

M 619/7. Avesnes strike (1889).

M 625/67. Avesnes strike (1895).

Archives Nationales de la France (AN)

$F^{12}$ 4665. Avesnes strike (1889).

Bourdieu, Pierre

1976 "Marriage Strategies as Strategies of Social Reproduction." In Robert Forster and Orest Ranum, eds., Family and Society. Selections from the Annales: Economies, Sociétés, Civilisations, 117-144. Baltimore Johns Hopkins University Press.

Braun, Rudolf

1966 "The Impact of Cottage Industry on an Agricultural Population." In David Landes, ed., The Rise of Capitalism, 53-64. New York: MacMillan.

Chatelain, Abel

1976 Les Migrants temporaires en France de 1800 à 1914. Lille: University of Lille III.

Dufrancatel, Christiane

1978 "Autobiographies de "femmes du peuple." Le Mouvement social 105:147-1S6. 
Felhoen, Dr. R.

1906 Etude Statistique sur la mortalité infantile à Roubaix et dans ses cantons. Paris: Vigot.

Fohlen, Claude

1956 L'industrie textile au temps du Second Empire. Paris: Plon.

Furet, François and Jacques Ozouf

1977 Lire et écrire. L'alphabétisation des français de Calvin à Jules Ferry. Paris: Editions de Minuit.

Grafteaux, Serge

1976 Mémé Santerre. Verviers: Marabout.

Laslett, Barbara

1978 "Strategies for Survival: An Historical Perspective on the Family and Development." Paper presented at the Ninth World Congress of Sociology, 1978.

Lawner, Lynne, ed.

1973 Letters from Prison by Antonio Gramsci. New York: Harper and Row.

Lentacker, Firmin

1950 "Les frontaliers belges travaillant en France: Caractères et fluctuations d'un courant de main-d'oeuvre." Revue du Nord 32:130-144.

Levine, David

1977 Family Formation in an Age of Nascent Capitalism. New York: Academic.

Macfarlane, Alan

1970 The Family Life of Ralph Josselin. Cambridge: Cambridge University Press.

1977 Reconstructing Historical Communities. Cambridge: Cambridge University Press.

Motte, Fernand

n.d. Souvenirs personnels d'une demi-siècle de vie et de pensée, 1886-1942. Lille: SILIC.

Perrot, Michelle

1974 Les Ouvriers en grève: France, 1871-1890. Patis, The Hague: Mouton.
Rapp, Rayna

1978 "Family and Class in Contemporary America: Notes toward an Understanding of Ideology." University of Michigan Papers in Women's Studies, Special Issue: 85-110.

Reardon, Judy Anne

1977 "Belgian Workers in Roubaix, France, in the Nineteenth Century." Doctoral dissertation, University of Maryland.

Reybaud, Louis

1867 La laine. Paris: Levy.

Roubaix, Ville de

1864 Rapport du Maire, 1863. Roubaix: Reboux.

1865 Rapportdu Maire, 1864. Roubaix: Reboux.

Thompson, E. P.

1977 "Happy Families: Review of Lawrence Stone. The Family, Sex and Marriage in England, 1500-1800." New Society, 8 September:499-501.

Tilly, Louise A.

1978 "Structure de l'emploi, travail des femmes et changements démographiques dans deux villes industrielles, Anzin et Roubaix, 1872 1906." Le Mouvement Social 105:33-58.

1979 "The Family Wage Economy in a French Textile City, Roubaix, 1872-1906." The Journal of Family History (Special Issue of David Center papers, forthcoming).

Tilly, Louise A. and Steven J. Dubnoff

1978 "Families and Wage Earning in Amiens and Roubaix, 1906: Measures of Income Adequacy and Household Response in Two French Cities." Unpublished paper presented at the Annual Meeting of the Social Science History Association. 